\title{
Flowering, Fruiting of Two Table Olive Cultivars "Olea europaea L." Grown in Southern Egypt
}

\author{
Zienab F. R. Ahmed \\ Department of Horticulture, Faculty of Agriculture, South Valley University, Qena \\ 83523, Egypt.
}

\begin{abstract}
$\mathbf{O}$
LIVE is an evergreen tree that is well adapted to hot and dry climate, but requiresspecific chilling units for flowering. Olive is grown for table usage and oil production that is known for its organoleptic properties and health benefits. The area of olive production is increased in the new cultivated land such as in south Egypt. The present study is conducted to evaluate the flowering behavior and fruit characteristics of two table olive cultivars (cvs.)' Toffahi 'and 'Aggizi' that firstly grown in southern Egypt (Qena) during seasons 2016 and 2017. The growth season began early in February as the flowering bud appeared. There was variation in floral behavior between the studied cultivars. 'Toffahi' cv. had significantly longer flowering shoot with higher number of inflorescence (IFC) compared to 'Aggizi' cv. The IFC in the top and middle of the shoots were longer than that in the base in both cultivars, however, the flower number per IFC located in the shoot top and middle was higher in 'Toffahi' than 'Aggizi' cv. Despite that there were significant differences in flower number/ IFC and perfect flower percentage between 'Toffahi' and 'Aggizi', the fruit set percentage was not significant. Although the initial fruit number per shoot was higher in'Toffahi' than 'Aggizi', the dropped fruits number was higher that making the final fruit number per shoot not significantly higher. The fruit characteristics such as: weight, size, length, width, flesh/stone ratio, moisture and oil contents were similar to the typical known for both cultivars.
\end{abstract}

Our results showedthatbothtableolive cultivars 'Toffahi' and 'Aggizi'were able to adapt the new condition andmaintained the regular floral behavior and good fruit characteristics, suggesting that these cultivars can successfully be grown under southern Egypt conditions.

Keywords: Flowering behavior, Inflorescence structure, Fruit set, Fruit characteristics.

\section{Introduction}

Olive trees has been cultivated in the Mediterranean region for thousands years. Olive isconsidered as a strategic crop for the economy of most Mediterranean countries. Table olive andolive oil arethe common and main components of the Mediterranean diet. Due to their organoleptic characteristics and medicinal values, olive consumption spread outside the Mediterranean region (Bertrand, 2002). Because of the increase in demand, cultivation areas need to be increased. However, the suitability of aregion for olive cultivation must be evaluated to avoid the negative effect on the fruit production and oil quality (Tous \& Romero, 1994 and Weiying et al., 1998).

Previous reports illustrated that various factors such asseasonal ecological conditions,cultivar genetic makeup and agricultural practices had a substantial influence on the vegetative growth, flowering and fruiting of the treeas well asthe oil production and quality (Martin et al., 2005). High temperatures during fruit growthled to slowingdown several critical functions and thus reducing fruit size and causing fruit shriveling (Ahmed \& Taha, 2018 and Lombardo et al., 2008). Flower bud induction and differentiation depends on many factors such as environmental conditions, hormonal balance and nutrition, while chilling during winter is required for flower bud opening (Fabbri and Benelli, 2000). The panicle structure, length and flower number varies among cultivars, treesand even shoots (Lavee et al., 2002 $\&$ Seifi et al., 2008). Insufficient chilling units and other environmental conditions of a region affect

Corresponding author : Zienab F. R. Ahmed, e-mail:zinabriad@yahoo.com, Tel. 01069476428

DOI : 10.21608/ejoh.2019.10065.1102

C2019 National Information and Documentation Centre (NIDOC) 
the compatibility within olive cultivars (Connor \& Fereres, 2005, Lavee et al., 2002, Martin et al., 2005 and Mookerjee et al., 2005).

Several olive cultivars are grown in thenorthern region of Egypt mainly for table usage and oil extraction. In Upper Egypt, olive is not common due to the harsh climate withwarm winter and hot summer that is not expected to provide the thermal requirements for bud induction, flowering and acceptable fruit quality of different cultivars. Southern Egypt region presents olive on about $1 \%$ of the total olive area in Egypt. To increase the cultivated area, field trial is one of the effective waysfor examining the suitability of this area to a specific olive cultivar thatwould lead to high economic returns for the grower. The present study is a field trial conducted in Qena governorate, Egypt. Qenahas a climate that is a very hot in summer and worm in winter. There is a wide range between day and night temperatures $\left(\approx 16^{\circ} \mathrm{C}\right)$, and low precipitation is recorded. Therefore, this study aims toinvestigate the floral habits, the productivity and fruit quality of two table olive cultivars grown under Qena governorate to recommend their suitability under prevailing conditions.

\section{Materials and Methods}

The present study was carried out at the research center of Horticulture Department, South Valley University, Qena, Egypt, during 2016 and 2017 seasons. Average ofthe monthly temperature through 2016, 2017 seasons was obtained from the meteorological stations located near the study area in Qenacity. Chilling units of this region was calculated by summating of all hours below $12 \mathrm{C}^{\circ}$ for the period from November to March ofeach season (2016 and 2017) according to Pérez López et al., 2008. Uniformity 5 trees of 7 years old were randomly selected from each table olive cultivar: 'Toffahi' and 'Aggizi' to evaluate the flowering and fruitingattributes as follows:

\section{Flowering attributes}

The date of all growth habits fromfloral bud swelling, inflorescence appearance, flower opening, fruit set, fruit color change until harvest, were recorded for each cultivars. All dates were recorded when about $10-15 \%$ of the phenomenon showed up on the trees.

Twenty of one year old flowering shoot were tagged to study their characteristics: the shoot Egypt. J. Hort. Vol. 46, No.1 (2019) length, total number of buds, number of flower buds, number of inflorescences per shoot and the distribution of flower buds on eachshoot. The inflorescences distribution on the shoot (Top, middle, base) and the inflorescence length, also flower number per inflorescence were recorded. Fifty inflorescences from each tree were tagged to observe the paniclemain structure (shape, number of branches, number of flowers per branch, and total number of flowers perpanicle) that found in each olive cultivar, according to Seifi et al., 2008. Another fifty panicles were tagged to determine thepanicle length, flowers number, perfect flowerspercentage (number of perfect flowers/total number of flowers \%), initial fruit set percentage (number of fruits/total number of flowers), and the initial fruit number per panicle. Twenty shoots were tagged to record the initial fruits number per shoot and twenty days after that the final fruit number and the dropped fruit numberper shoot were recorded.

\section{Fruiting}

At harvest, a group of 100 fruits from each tree were collected randomly to determine: fruit weight, length, width as well as stone and flesh weight. Fruits were oven dried at $105^{\circ} \mathrm{C}$ for $48 \mathrm{hrs}$ to determine fruit moisture percentage, and the oil content based on the fruit dry weight by Soxhelt (A.O.A.C., 2000).

\section{Statistical analysis}

The experimental design of this study was the randomized complete blocks design. The mean values between cultivars in both seasons 2016 and 2017 were analyzed by $\mathrm{T}$ test at probability level of $5 \%(\mathrm{P} \leq 0.05)$. Means comparisons for the flowers number and for the IFC length of different IFC positions for each cultivars were analyzed by LSD test at $\mathrm{P} \leq 0.05$ using PROC GLM procedure of Statistical Analysis System (SAS) version 9.2 for Windows, SAS Institute Inc., Cary, NC, USA (SAS®, 2009).

\section{Results and Discussion}

Table 1 presented the average temperature for Qena Governorate during 2016 and 2017 seasons, the number of chilling hours below $12 \mathrm{C}^{\circ}$ for this region was found to be 550 and $790 \mathrm{hr}$ for the 2016 and 2017 seasons, respectively. In this study, results provide evaluation of flowering behavior and fruit characteristics for the two table olive cultivars 'Toffahi' and 'Aggizi' that firstly grown in southern Egypt (Qena governorate). 
TABLE 1. Monthly temperature for Qena Governorate during 2016 and 2017 seasons.

\begin{tabular}{|c|c|c|c|c|c|}
\hline \multicolumn{3}{|c|}{ Season 2016} & \multicolumn{3}{|c|}{ Season 2017} \\
\hline & Max. $\left({ }^{\circ} \mathbf{C}\right)$ & Min. $\left({ }^{\circ} \mathrm{C}\right)$ & & $\operatorname{Max} .\left({ }^{\circ} \mathrm{C}\right)$ & Min. $\left({ }^{\circ} \mathrm{C}\right)$ \\
\hline Nov 2015 & 29.8 & 16.6 & Nov 2016 & 29.6 & 15.7 \\
\hline Dec 2015 & 22.5 & 9.6 & Dec 2016 & 21.4 & 8.4 \\
\hline Jan 2016 & 20.6 & 6.8 & Jan 2017 & 21.9 & 7.6 \\
\hline Feb 2016 & 26.6 & 10.8 & Feb 2017 & 23.3 & 8.4 \\
\hline Mar 2016 & 30.5 & 16.1 & Mar 2017 & 28.2 & 13.2 \\
\hline Apr 2016 & 36.5 & 20.4 & Apr 2017 & 34.8 & 19 \\
\hline May 2016 & 39.2 & 23.5 & May 2017 & 38.6 & 23.2 \\
\hline Jun 2016 & 39.7 & 25 & Jun 2017 & 39.4 & 24.5 \\
\hline July 2016 & 40.5 & 26.6 & July 2017 & 39.5 & 25.7 \\
\hline Aug 2016 & 40.6 & 26.1 & Aug 2017 & 41.1 & 25.9 \\
\hline Sep 2016 & 38.9 & 23.2 & Sep 2017 & 38.3 & 22.2 \\
\hline Oct 2016 & 35 & 20.5 & Oct 2017 & 34.3 & 20.5 \\
\hline
\end{tabular}

Number of chilling hours $\leq 12$ from November to March

550

790

Blooming and fruiting dates

'Toffahi' and 'Aggizi'are early cultivars as the growing season began in the third week of February when the flower buds appeared. The initial boom wasin the second week of March for 'Toffahi' and the lastweek of March for 'Aggizi' (Table 2).

TABLE 2. Dates of flowering and fruit growth for two table olive cultivars during 2016.

\begin{tabular}{lcccc}
\hline \multirow{2}{*}{$\begin{array}{c}\text { Cultivar } \\
\text { Season }\end{array}$} & \multicolumn{2}{c}{ Toffahi } & \multicolumn{2}{c}{ Aggizi } \\
\cline { 2 - 5 } & $\mathbf{2 0 1 6}$ & $\mathbf{2 0 1 7}$ & $\mathbf{2 0 1 6}$ & $\mathbf{2 0 1 7}$ \\
\hline Flower bud appearance & 14-Feb & 19-Feb & 20-Feb & 13-Feb \\
Flowering & 8-Mar & 13-Mar & 27-Mar & 23-Mar \\
Fruit set & $15-\mathrm{Mar}$ & 18-Mar & 1-Apr & 28-Mar \\
Fruit appearance & 15-Mar & 20-Mar & 3-Apr & 30-Mar \\
Color Change to white & 25-Jun & 20-Jun & 25-Jun & 20-Jun \\
Color Change to purple & 1-Aug & 25-Jun & 1-Aug & 25-Jun \\
Harvest date & 6-Aug & 1-Aug & 6-Aug & 1-Aug \\
\hline
\end{tabular}

The full bloom and fruit set began in the second and last week of March for both cultivars. By the end of blooming, small new fruitswere noticed in the second week of March in 'Toffahi' and in the first week of April in 'Aggizi'. Fruits color began to change from green to white in June $20^{\text {th }}$, and to purple in August $1^{\text {st }}$ for both cultivars. When about $10-15 \%$ of the fruit changed their color to purple, both cultivars were harvested (Fig.1).
The dates of Blooming/fruiting of these cultivars were two weeks earlier under southern regions conditionsthan under the northern region of Egypt (Abbas and El-Khoreiby, 1988) and similar to that under Sohage condition (Saad ElDin et al., 2010). Beginning of the growing season and the duration of blooming varied from cultivar to cultivar and wereaffect by the environmental factors and topography of different region (Orlandi et al., 2005 and Pérez López et al., 2008). 


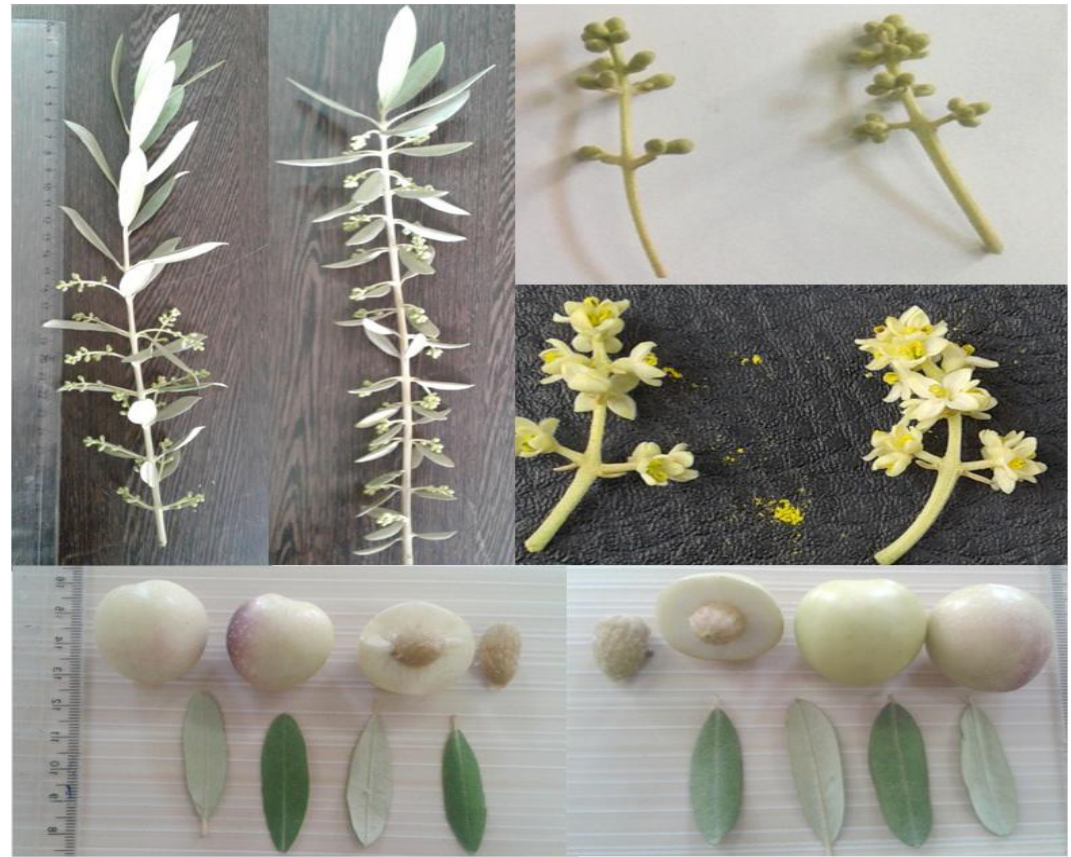

Aggizi

Toffahi

Fig. 1. One year old shoot, inflorescence, fruit of two table olive cultivars 'Aggizi' left and 'Toffahi' right.

\section{Floral behavior}

The floral characteristics of one year old shoot are presented in Table 3. The average shoot length of 'Toffahi' was longer $(23.4 \mathrm{~cm})$ than that of 'Aggizi' (20.7cm). The average number of buds per shoot was 20.8 and 18.3 for 'Toffahi' and 'Aggizi', respectively. The number of flower buds per shoot was significantly higher in 'Toffahi' (13.5) than that of 'Aggizi' (7.5). 'Toffahi' had shoot withsignificantly higher number of buds with double inflorescences (3.8), that reflectsthe higher number of inflorescences per shoot (18.6) compared to 'Aggizi' cultivar (Table 3).

Several factors influence bud induction and differentiation in olive such as winter temperature, tree nutritional status and hormonal balance (Lavee et al., 1996). The shoots tended to bear their floral buds on the third node and along the shoot to the top in 'Toffahi' while' Aggizi' shootsbore floral buds on the first two thirds of the shoot (Fig. 1), this behavior may be unique characteristic for each cultivar.

Influence of the inflorescence position, on the shoot (Top, middle, base), on inflorescence length and flower number per inflorescence were presented in (Table 3). In both studied cultivars, Egypt. J. Hort. Vol. 46, No.1 (2019) the top and the middle position of the shoot had long panicles, but the panicle in the top had significantly the highest number of flowers while the shortest panicle in the base had significantly lower number of flowers. This trend was similar in both growing seasons. These results are in agreement with the previous report cleared that the location of the inflorescence on the shoot had significant effects on the panicle length and the flowers number in olive cultivars grown in different regions (Seifi et al., 2008).

\section{Inflorescence structure and characteristics}

Inflorescences of different olive cultivars were noticed to have several structure patterns. There are 6 panicle structures were observed in the studied cultivars, and labeled by numbers from 1 to 6 (Fig. 2).

All of them were found on the 'Toffahi' shoots except structure \#5 with flowers number ranged between 11-29. The main structures were noticed in 'Aggizi' shoot (2,3,4 and 5) with flowers number ranged between 9 and 22. The inflorescence architecture was found to be as wide-rangingfrom cultivar to another in olive trees according to Seifi et al. (2008). 
TABLE 3. Flowering shoot characteristics and inflorescence position effect on inflorescence characteristics of the two table olive cultivars .

\begin{tabular}{|c|c|c|c|c|c|c|}
\hline & \multicolumn{6}{|c|}{ Shoot characteristics (2016 season) } \\
\hline & $\begin{array}{l}\text { Shoot length } \\
\text { (cm) }\end{array}$ & $\begin{array}{l}\text { Bud/shoot } \\
\text { (No) }\end{array}$ & $\begin{array}{c}\text { Buds with IFC } \\
\text { (No) }\end{array}$ & $\begin{array}{l}\text { Buds with two } \\
\text { IFC (No) }\end{array}$ & $\begin{array}{l}\text { Buds with IFC } \\
\text { location }\end{array}$ & $\begin{array}{l}\text { IFC/shoot } \\
\text { (No) }\end{array}$ \\
\hline Toffahi & $23.4 \pm 0.32^{*}$ & $20.8 \pm 0.40^{*}$ & $13.5 \pm 0.32^{*}$ & $3.8 \pm 0.02$ & $3-18 \pm 0.10$ & $18.6 \pm 0.27^{*}$ \\
\hline \multirow[t]{2}{*}{ Aggizi } & $20.7 \pm 0.27$ & $18.3 \pm 0.33$ & $7.5 \pm 0.22$ & $2.4 \pm 0.11$ & $3-13 \pm 0.13$ & $12 \pm 0.20$ \\
\hline & \multicolumn{6}{|c|}{ Shoot characteristics (2017 season) } \\
\hline Toffahi & $25.4 \pm 0.31^{*}$ & $24.3 \pm 0.23^{*}$ & $15.2 \pm 0.28^{*}$ & $3.8 \pm 0.02$ & $3-20 \pm 0.08$ & $17.6 \pm 0.22^{*}$ \\
\hline \multirow[t]{4}{*}{ Aggizi } & $23.3 \pm 0.40$ & $20.4 \pm 0.52$ & $9.6 \pm 0.26$ & $3.2 \pm 0.09$ & $3-14 \pm 0.11$ & $13.1 \pm 0.18$ \\
\hline & \multicolumn{6}{|c|}{ Inflorescence position on shoot (2016 season) } \\
\hline & \multicolumn{2}{|c|}{ Top } & \multicolumn{2}{|c|}{ Middle } & \multicolumn{2}{|c|}{ Base } \\
\hline & $\begin{array}{l}\text { IFC length } \\
(\mathrm{cm})\end{array}$ & $\begin{array}{c}\text { Flower } \\
\text { (No) }\end{array}$ & $\begin{array}{l}\text { IFC length } \\
(\mathrm{cm})\end{array}$ & $\begin{array}{c}\text { Flower } \\
(\mathrm{No})\end{array}$ & $\begin{array}{l}\text { IFC length } \\
(\mathrm{cm})\end{array}$ & $\begin{array}{l}\text { Flower } \\
(\mathrm{No})\end{array}$ \\
\hline Toffahi & $3.5 \pm 0.04^{\mathrm{A}}$ & $25.2 \pm 0.21^{* a}$ & $3.5 \pm 0.04^{\mathrm{A}}$ & $25.6 \pm 0.24^{* a}$ & $1.5 \pm 0.04^{\mathrm{B}}$ & $11 \pm 0.11 \mathrm{~b}$ \\
\hline \multirow[t]{2}{*}{ Aggizi } & $3.5 \pm 0.03^{\mathrm{A}}$ & $20.2 \pm 0.17^{\mathrm{a}}$ & $3.5 \pm 0.03^{\mathrm{A}}$ & $15 \pm 0.20^{\mathrm{b}}$ & $2.0 \pm 0.06^{\mathrm{B}}$ & $12 \pm 0.15^{\mathrm{c}}$ \\
\hline & \multicolumn{6}{|c|}{ Inflorescence position on shoot (2017 season) } \\
\hline Toffahi & $3.5 \pm 0.02^{\mathrm{A}}$ & $29.0 \pm 0.18^{* a}$ & $3.5 \pm 0.04^{\mathrm{A}}$ & $22.0 \pm 0.31^{* \mathrm{~b}}$ & $1.5 \pm 0.02^{\mathrm{B}}$ & $11 \pm 0.08^{c}$ \\
\hline Aggizi & $3.5 \pm 0.03^{\mathrm{A}}$ & $22.3 \pm 0.23^{\mathrm{a}}$ & $3.5 \pm 0.03^{\mathrm{A}}$ & $13 \pm 0.25^{\mathrm{b}}$ & $2.0 \pm 0.04^{\mathrm{B}}$ & $11 \pm 0.09^{b}$ \\
\hline
\end{tabular}

$\mathrm{IFC}=$ Inflorescence, $\mathrm{No}=$ number, ${ }^{*}$ represents the significance between the cultivars means within a season, $(\mathrm{rep}=5$ and $\mathrm{n}=100) . \mathrm{Mean}$ comparisons for the flowers number and for the IFC length of different IFC positions for each cultivars were made using LSD test. Different letter indicates significant difference within a row at $\mathrm{P} \leq 0.05$.

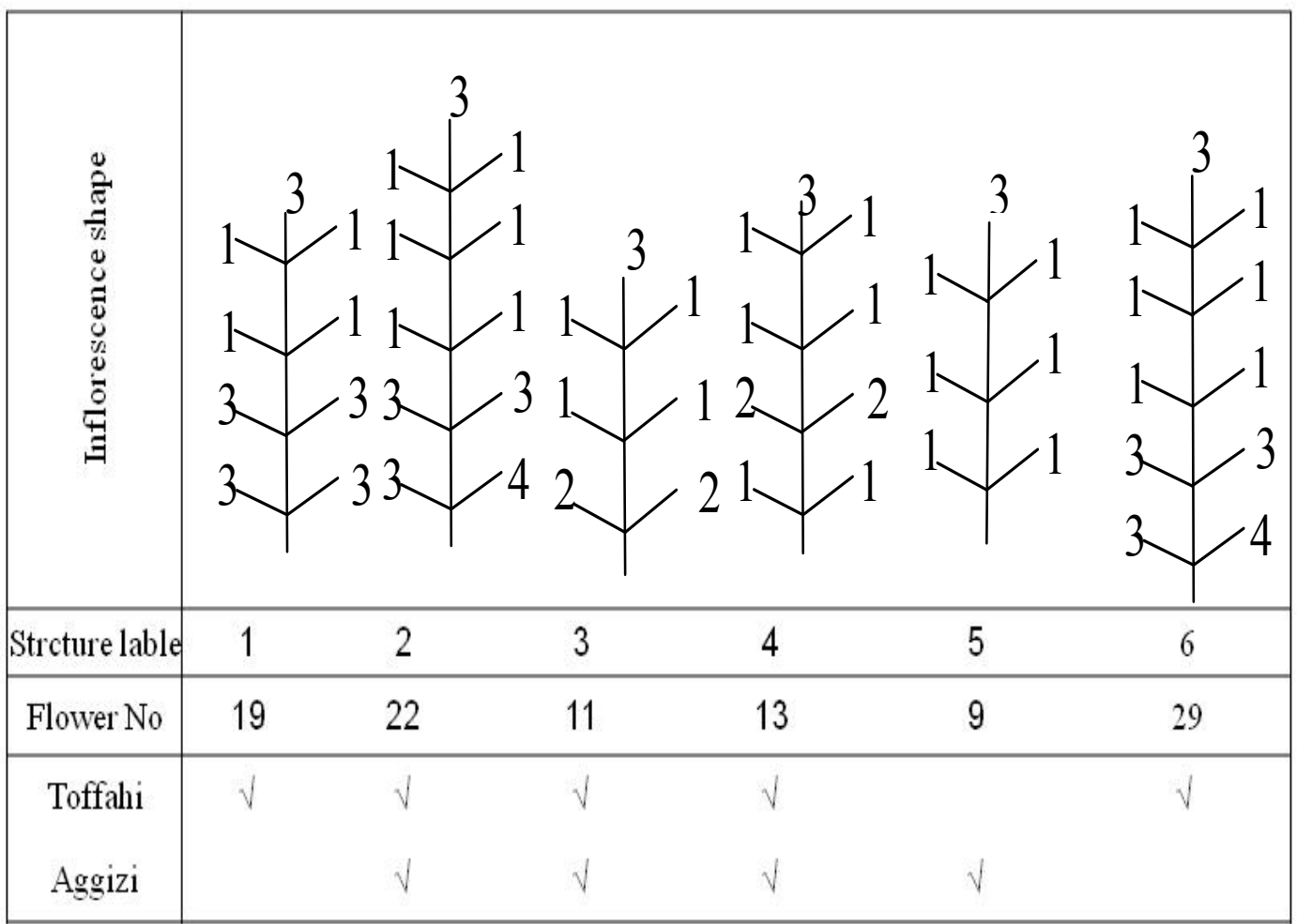

Fig. 2. Inflorescence main structuresobserved on the two table olive cultivars 'Aggizi' and 'Toffahi', (rep $=5$ and $\mathrm{n}=\mathbf{5 0 0})$. 
Results in Table 4 show thatinflorescence length and flower number varied from shoot to shoot, tree to tree, cultivar to cultivar and from year to year as early reports (Lavee et al., 1996, Lavee et al., 2002 and Seifi et al., 2011). Panicle length of' Toffahi 'and 'Aggizi'cvs. was not significantly different, but the flower number was higher in 'Toffahi'. The number of flowers on panicles varied due to their main structures that have different number of flowers (Fig. 2). These results demonstrate that inflorescencecharacteristics are differ with inolive cultivars and could be used to identify each cultivar.

The perfect flower percentage was higher in 'Aggizi' cv. (7.6- 72\%) compared to 'Toffahi' that had 37.3- 47.4\% in 2016 and 2017 seasons, respectively. Despite this high percentage in 'Aggizi', the percentage of initial fruit set was not significantly different in both cultivars. These result may be relatively due to self-incompatibility or other factors that affect pollination such as high temperature or dry wind (Connor \& Fereres, 2005 and Moutier, 2002). The average initial fruit retention per inflorescence after fruit set ranged between 4.4-6.4/IFC, and 15.3- 20/shoot for both cultivars, and sharply decreased after 20 days to be from 1.4 to 2.6 fruits/ IFC and 7.3 to 8.2 fruits/ shoot as a result of competition. The dropped fruit number was lower in 'Aggizi' (6.3) than 'Toffahi' (11.7 fruit).

TABLE 4. Inflorescence characteristics of the two table olive cultivars.

\begin{tabular}{|c|c|c|c|c|}
\hline \multicolumn{2}{|c|}{ Aggizi } & \multicolumn{2}{|c|}{ Toffahi } & \multirow[b]{2}{*}{ Inflorescence characteristics } \\
\hline 2017 & 2016 & 2017 & 2016 & \\
\hline $2.5 \pm 0.02$ & $2.9 \pm 0.04$ & $2.9 \pm 0.03$ & $3.1 \pm 0.05$ & IFC Length (cm) \\
\hline $14.1 \pm 0.08$ & $16.1 \pm 0.12$ & $22.6 \pm 0.23^{*}$ & $20.6 \pm 0.17^{*}$ & Flower No / IFC \\
\hline $72.6 \pm 0.33^{*}$ & $57.6 \pm 0.40^{*}$ & $47.4 \pm 0.45$ & $37.3 \pm 0.69$ & Perfect flower (\%) \\
\hline $21.3 \pm 0.28$ & $23.1 \pm 0.34$ & $23.8 \pm 0.28$ & $20.2 \pm 0.33$ & Initial fruit set (\%) \\
\hline $4.4 \pm 0.12$ & $6.4 \pm 0.08$ & $5.3 \pm 0.19$ & $6.2 \pm 0.21$ & Initial fruit No / IFC \\
\hline $1.5 \pm 0.04$ & $1.4 \pm 0.04$ & $2.6 \pm 0.04$ & $2.1 \pm 0.05$ & Final fruits No / IFC \\
\hline $15.3 \pm 0.17$ & $16 \pm 0.25$ & $20 \pm 0.26^{*}$ & $19 \pm 0.23^{*}$ & Initial fruit No /shoot \\
\hline $7.5 \pm 0.15$ & $8.2 \pm 0.18$ & $8.1 \pm 0.12$ & $7.3 \pm 0.14$ & Final fruit No/shoot \\
\hline $6.3 \pm 0.28$ & $6.8 \pm 0.31$ & $10.5 \pm 0.04^{*}$ & $11.7 \pm 0.04^{*}$ & Dropped fruit No \\
\hline \multicolumn{5}{|c|}{ Fruit physical characteristics } \\
\hline 2017 & 2016 & 2017 & 2016 & \\
\hline $8.9 \pm 0.20$ & $9.2 \pm 0.19$ & $9.6 \pm 0.19$ & $9.8 \pm 0.17$ & Fruit weight (g) \\
\hline $2.4 \pm 0.04$ & $2.5 \pm 0.04$ & $2.7 \pm 0.04$ & $2.7 \pm 0.03$ & Fruit length $(\mathrm{cm})$ \\
\hline $2.3 \pm 0.03$ & $2.3 \pm 0.02$ & $2.5 \pm 0.03$ & $2.5 \pm 0.02$ & Fruit width (mm) \\
\hline $7.8 \pm 0.05$ & $8.1 \pm 0.08$ & $8.2 \pm 0.09$ & $8.4 \pm 0.13$ & Flesh weight (g) \\
\hline $1.0 \pm 0.02$ & $1.1 \pm 0.04$ & $1.1 \pm 0.02$ & $1.2 \pm 0.02$ & Stone weight (g) \\
\hline $87.8 \pm 0.44$ & $88.5 \pm 0.58$ & $85.2 \pm 0.54$ & $85.6 \pm 0.64$ & Flesh/fruit (\%) \\
\hline $11.4 \pm 0.36$ & $12.0 \pm 0.53$ & $11.2 \pm 0 . .22$ & $11.4 \pm 0.19$ & Stone/fruit (\%) \\
\hline $69.9 \pm 0.53$ & $70.7 \pm 0.48$ & $73.4 \pm 0.61$ & $72.8 \pm 0.52$ & Moisture (\%) \\
\hline $11.5 \pm 0.40$ & $11.3 \pm 0.51$ & $11.4 \pm 0.33$ & $10.7 \pm 0.43$ & Oil content (\%) \\
\hline
\end{tabular}

$\mathrm{IFC}=$ Inflorescence, $\mathrm{No}=$ number, ${ }^{*}$ represents the significance between the cultivars means within a season, $(\mathrm{rep}=5 \mathrm{and} \mathrm{n}=500)$.

Egypt. J. Hort. Vol. 46, No.1 (2019) 
This may be due to the variation in fruit set time, so the early fruits set became larger and retained while the late set fruitdid not continue growing and fall. In parallel with theprevious report, it showedthat the competition between fruit at bloom and after fruit set is inversely proportion to the size of flower and fruit (Rosati et al., 2010).

\section{Fruit characteristics}

Fruit characteristics of the studied cultivars during 2016 and 2017 seasons are presented in Table 4. 'Toffahi' and 'Aggizi' fruits were big in size and weight. 'Toffahi' had fruit weighed of $9.8 \mathrm{~g}$ while 'Aggizi' was 9.2g. There were no significant differences between the cultivars for the fruit size, flesh weight, stone weight. These values for the fruit characteristics of' 'Toffahi' and 'Aggizi' cvs.is dramatically affected by the hot summer and dry wind during fruit growth that increases water evaporation from the fruit (Ahmed and Taha, 2018, Fayek et al., 2014 and Shaheen et al., 2011).'Toffahi' and 'Aggizi' cvs. are table olive so that the fruits were harvested when the color began toturnlight green or shade purple (Fig. 2). The oil content for these two cultivars is known to be low, results in Table 4 show these values (10.7 and $11.5 \%)$ that are lower than that reported for both cultivars previously (Saad ElDin et al., 2010). Oil biosynthesis in olive fruits is affected by cultivar genetic makeup and growing conditions (Al-Maaitah et al., 2009 and Lavee \& Wodne, 2004). Fruit moisture ranged between 69.9 and $3.4 \%$ for both cultivars. These values werelower than those reported earlier about these cultivars (Saad El-Din et al., 2010). It is suggested that hot weather and low precipitation during fruit ripening may accelerateevaporation processand increase the respiration rate, which reduces the moisture contents in the fruit (Al-Maaitah et al., 2009 and Tombesi et al., 1994).

\section{Conclusion}

The present study results demonstrated that thetable cultivars 'Toffahi' and 'Aggizi'can successfully adapt to the new conditions of southern Egypt. Eachcultivars have normal growth and regularfloralbearing habit, flowering behavior and fruit production that prove their tolerance to the specific condition of southern Egypt.

\section{Acknowledgment}

The author would like to send great appreciation and thankful to College of Agriculture, South Valley University, Qena, Egypt for the financial support and funding of this project.

\section{Funding statements}

This research is funded by College of Agriculture, South Valley University, Qena, Egypt.

\section{Conflict of interest}

No conflicts of interest were declared.

\section{$\underline{\text { References }}$}

Abbas, M.T. and El-khoreiby, A.M.K. (1988) Floral behavior and fruiting of six olive cultivars grown under Ismailia condition. Egypt. J. Appl. Sci., 3, 288-296.

Ahmed, Z.F.R. and Taha. E.M. (2018) Fruit characteristics and olive oil quality in response to some environmental factors. Acta Hort., 1216, 1926.

A.O.A.C (2000) Offecial Methods of Analysis, Association of offecial analytical chemists, $5^{\text {th }} \mathrm{ed}$, Arlington, Virginia, USA.

Al-Maaitah, M.I., Al-Absi, K.M., and Rawashdeh, A.A. (2009) Oil quality and quantity of three olive cultivars as influenced by harvesting date in the middle and southern parts of Jordan. Int. J. Agric. Biol.,11, 266-272.

Bertrand, E. (2002) The beneficial cardiovascular effects of the Mediterranean diet Olivae, 90, 29-31.

Connor, D.J., and Fereres, E. (2005) The physiology of adaptation and yield expression in olive. Hort. Rev., 31, 155-229.

Fabbri, A., and Benelli, C. (2000) Review Article Flower bud induction and differentiation in olive. J. Hort. Sci. Biotechnol.,75, 131-141.

Fayek, M.A., Abdel-Mohsen, M.A., Laz, S.I., and ElSayed, S.M. (2014) Morphological, agronomical and genetic characterization of Egyptian olive clones compared with the international cultivars. Egypt J. Hort.,41, 59- 82.

Lavee, S., Rallo, L., Rapoport, H.F., and Troncoso, A. (1996) The floral biology of the olive: Effect of flower number, type and distribution on fruit set. Sci. Hort.,66, 149-158.

Lavee, S., Taryan, J., Levin, J., and Haskal, A. (2002) The significance of cross-pollination for various olive cultivars under irrigated intensive growing conditions. Olivae, 91, 25-36.

Lavee, S., and Wodne, M. (2004) The effect of yield, harvest time and fruit size on the oil content in fruits of irrigated olive trees (Olea europea), cvs. Barnea and Manzanillo. Sci. Hort., 99, 267-277.

Egypt. J. Hort. Vol. 46, No.1 (2019) 
Lombardo, N., Marone, E., Alessandrino, M., Giodino, G., Madeo, A. and Fiorino, P. (2008) Influence of growing season temperatures on the fatty acids (FAs) of triacylglycerols (TAGs) composition in Italian cultivars of Olea europaea. Adv. Hort. Sci., 22, 49-53.

Martin, G.C., Ferguson, L., and Sibbett, G.S.M. (2005) Flowering, pollination, fruiting, alternate bearing, and abscission', pp. 49-54. In: Sibbett, G.S., Ferguson, L., Coviello, J.L., and Lindstrand, M. (Ed.). Olive Production Manual. University of California, Agriculture and Natural Resources, Oakland, California.

Mookerjee, S., Guerin, J., Collins, G., Ford, C., and Sedgley, M. (2005) Paternity analysis using microsatellite markers to identify pollen donors in an olive grove. Theor. Appl. Genet.,111, 1174-1182.

Moutier, N. (2002) Self-fertility and intercompatibilities of sixteen olive varieties. Acta Hort., 586, 209-212.

Orlandi, F., Vazquez, L.M., Ruga, L., Bonofiglio, T., Fornaciari, M., Garciamozo, H., Dominguez, E., Romano, B., and Galan, C. (2005) Bioclimatic requirements for olive flowering in two Mediterranean region located at the same latitude (Andalucia,Spain and Sicily, Italy. Ann. Agric. Environ., 12, 47-52.

Pérez López, D., Ribas, F., Moriana, A., Rapoport, H., and De Juan, A. (2008) Influence of temperature on the growth and development of olive (Olea europaea L.). J. Hort. Sci. Biotechnol., 83,171-176.

Rosati, A., Zipancic, M., Caporali, S., and Paoletti, A. (2010) Fruit set is inversely related to flower and fruit weight in olive (Olea europaea L.). Sci. Hort., 126, 200-204.

Saad El-Din, I., El-Taweel, A.S., and El-Bolok, T.K. (2010) Evaluation of some olive cultivars grown under Sohag governorate conditions. Egypt J. Hort., 37, 235-256

SAS ${ }^{\circledR}$, I.I. (2009) SAS Online Doc. Version 9. 2 Copyright 2009. SAS Institute Inc, Cary, NC, USA

Seifi, E., Guerin, J., Kaiser, B., and Sedgley, M. (2008) Inflorescence architecture of olive. Sci. Hort, 116, 273-279.

Seifi, E., Guerin, J., Kaiser, B., and Sedgley, M. (2011) Sexual compatibility and floral biology of some olive cultivars. New Zealand J. Crop Hort. Sci., 39, 141-151

Egypt. J. Hort. Vol. 46, No.1 (2019)
Shaheen, A.S., El-Taweel, A.A., and Al-Khateeb, A. (2011) Effect of using olive vegetation water (OVW) on growth, flowering and yield of Manzanillo olive trees. J. Amer. Sci., 7, 501-508.

Tombesi, A., Pilli, M., Boco, M., and Proietti, P. (1994) Evolution of olive fruit respiration, photosynthesis and oil composition during ripening. Acta Hort., 356, $420-445$.

Tous, J., and Romero, A. (1994) Cultivar and location effects on olive oil quality in Catalonia, Spain. Acta Hort., 356, 323-326.

Weiying, X., Mingquanand, D., and Ning, Y. (1998) Studio delle regioni cineci all oliviculture. Olivae, 70, 19-31.

(Received 27/02/2019; accepted 12/04/2019) 


\title{
الازهار والاثمار لصنفين من زيتون المائدة النامية تحت ظروف جنوب مصر \\ زينب فوزى رياض احمد

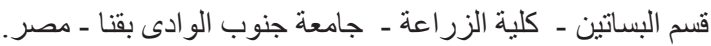

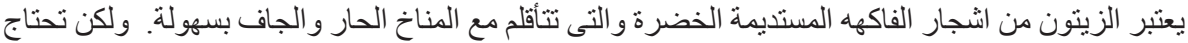

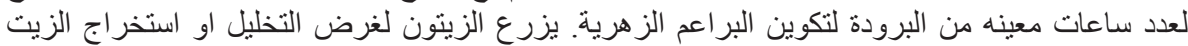

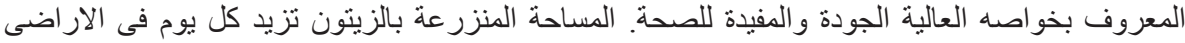

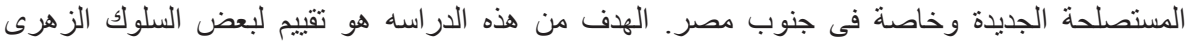

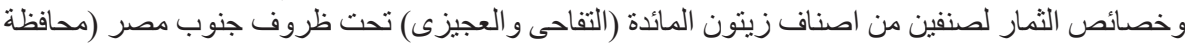

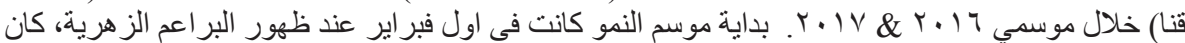

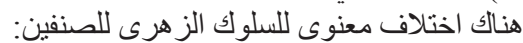

• الفرع الحامل للاز هار كان اطول و اكثر فى عدد العناقيد الزهريه فى التفاحى عن العجيزى. • العناقيد الز هريه فى قمة ووسط الفرع كانت اطول وبها از هار اكثر من التى فى اسفل الفرع. • عدد الازهار للعنقود الزهرى كانت اكبر فى التفاحى عن العجيزى.

• • • عدد الثمار العاقدة مبدئيا كان عالى وانخفض مع الوقت نتيجة المنافسة . • الثمار كانت كبيره الحجم و الوزن ولكن لم يكن هناك فروق فى الخو اص الثمريه ونسبة الزيت و الرطوبة

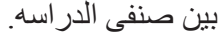
من النتائج السابقه يمكن النصح بزر اعة هذان الصنفان تحت ظروف قنا لنا لانهما اثبتا تأقلم تام ونمو جيد

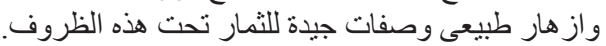

